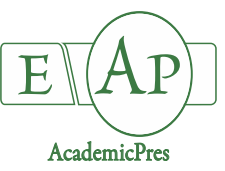

Torres-Rodriguez JA et al. (2021)

Notulae Botanicae Horti Agrobotanici Cluj-Napoca

Volume 49, Issue 1, Article number 12231

DOI: $10.15835 /$ nbha 49112231

Review Article

\title{
A biopolymer with antimicrobial properties and plant resistance inducer against phytopathogens: Chitosan
}

\section{Juan A. TORRES-RODRIGUEZ ${ }^{1}$, Juan J. REYES-PÉREZ²*, Thelma CASTELLANOS ${ }^{1}$, Carlos ANGULO ${ }^{1}$, Evangelina E. QUIÑONES-AGUILAR ${ }^{3}$, Luis G. HERNANDEZ-MONTIEL ${ }^{1 *}$}

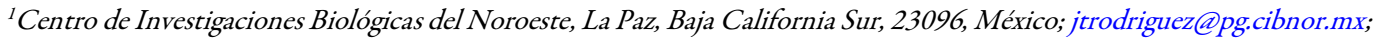 \\ tcastell@cibnor.mx; cangulo@cibnor:mx; Ihernandez@cibnor:mx ("corresponding author) \\ ${ }^{2}$ Universidad Técnica Estatal de Quevedo, Quevedo EC 120501, Los Ríos, \\ Ecuador; jreyes@uteq.edu.ec ("correspondingauthor) \\ ${ }^{3}$ Centro de Investigaciones y Asistencia en Tecnología y Diseño del Estado de Jalisco, Guadalajara, 44270, \\ México; equinones@ciatej.mx
}

\begin{abstract}
Some synthetic fungicides have been currently prohibited due to their adverse effects; thus, searching for alternatives to decrease their application is a priority worldwide. An alternative to the application of synthetic fungicides is chitosan -a natural biopolymer- because of its biocompatibility, biodegradability, and bioactivity. Chitosan has been used in different industries, such as cosmetology, pharmaceutics, food, among others. In agriculture, it has been used as a resistance inductor and bio-fungicide because of its antimicrobial activity and for plant development as growth promoter. Although many works have been published on chitosan for its characteristics and mode of action, the direct effects on agriculture -both in plant and fruit phytopathogens- have not been reported. Therefore, the objective of this review is to summarize recent advances and achievements of chitosan application in agriculture with special attention to its antimicrobial properties and plant defence induction mechanisms.
\end{abstract}

Keywords: antimicrobial activity; induced systemic resistance; main sources of chitin; fruit protection; chitosan nanoparticles

\section{Introduction}

Synthetic fungicides have an important role in phytopathogen control (Massi et al., 2021). Nonetheless, their application generates resistance to phytopathogens and affects the environment, human and animal health negatively (Meena et al., 2020b). Currently, interest exists in friendly agriculture that produces healthy food and minimizes the use of agrochemicals (Baker et al., 2020). Using biopolymers, such as cellulose, starch, galactomannan, among others, has gained importance for controlling diverse plant diseases (Malerba and Cerana, 2018) where chitosan stands out as the most used biopolymer in agriculture (Yang et al., 2021).

Received: 20 Jan 2021. Received in revised form: 17 Feb 2021. Accepted: 24 Feb 2021. Published online: 02 Mar 2021.

From Volume 49, Issue 1, 2021, Notulae Botanicae Horti Agrobotanici Cluj-Napoca journal will use article numbers in place of the traditional method of continuous pagination through the volume. The journal will continue to appear quarterly, as before, with four annual numbers. 
Chitosan is extracted from chitin found in the exoskeleton of crustaceans (Fournier et al., 2020), fungal cell wall (Chang et al., 2019), insect cuticle (Luo et al., 2019), among others. Chitosan has been used in waste water treatment (Uragami et al., 2015), cosmetology (Aranaz et al., 2018), medicine (Ahsan et al., 2018), pharmaceutics (Khan et al., 2019), food and beverage (Rocha et al., 2017), and paper industries (Song et al., 2018), among others.

In agriculture, chitosan has been used to induce plant resistance (Coutinho et al., 2020), increasing the antagonistic capacity of beneficial microorganisms (El Amerany et al., 2020) and crop productivity (Rahman et al., 2018). In phytopathogen control, chitosan induces morphological changes and structural alterations in fungal cells that cause cell death (Berger et al., 2016). When chitosan is used to improve plant defense, it induces reactive oxygen species (ROS) production (Silva et al., 2018), hydrolytic enzymes (Obianom et al., 2019), pathogenesis-related (PR) proteins (Liu et al., 2019), phytoalexins (Gai et al., 2019), callose formation (de Lamo et al., 2020), and promotes lignification (Jiang et al., 2018). Chitosan structure, synthesis and antimicrobial properties in vitro have been discussed widely (Verlee et al., 2017), but few studies have focused on its effects on agriculture.

\section{Chitosan}

\section{Chemical characteristics and main sources}

Chitosan is the most important chitin by-product, which is obtained by thermo-alkaline deacetylation. It is a lineal polymer formed by N-D glucosamine (2-amino-2-deoxy- $\beta$-D glucopyranose) monomers, bound by $\beta-1-4$ (Katiyar et al., 2015). Chitin is a natural and abundant biopolymer found in many organism (Fournier et al., 2020; López-Corona et al., 2020) (Table 1) and is compound of 2-acetylamine-2-deoxy- $\beta$-Dglucopyranose units (Peter et al., 2020).

Table 1. Main sources of chitin

\begin{tabular}{|c|c|c|}
\hline Source & Specie & Reference \\
\hline Cockroach & Periplaneta americana & Kaya et al., 2015a \\
\hline Spider & Caribena versicolor & Machałowski et al., 2019 \\
\hline Scarab & Goliathus orientalis & Fournier et al., 2020 \\
\hline Crab & Portunus segnis & Hamdi et al., 2017 \\
\hline Bryozoa & Plumatella repens & Kaya et al., 2015b \\
\hline Mollusk & Chiton sp. & Sayari et al., 2017 2016 \\
\hline Norway lobster & Nephrops norvegicus & Srinivasan et al., 2018 \\
\hline Shrimp & Penaeus monodon & Sun et al., 2018 \\
\hline Yeast & Saccharomyces cerevisiae & Aili et al., 2019 \\
\hline Fungus & Penicillium camembertii &
\end{tabular}

The main forms of application of chitosan are: seed coating, soil enrichment, foliar spraying, fruit coating, nanoparticles, among others (Morin-Crini et al., 2019). Chitin is white or yellowish in its pure state and highly hydrophobic, thus, insoluble in water and on organic solvents (Cheba, 2011). To obtain chitin, chemical and biological methods are used. The first one has a disadvantage (environmental pollution due to generated waste), but its short processing time turns it into the most commercially used (Hamed et al., 2016). This method implies three steps; demineralization, deproteinization and discoloration (Figure 1). The first step consists of processing raw matter in dust with strong acids (hydrochloric acid $[\mathrm{HCl}]$, sulfuric acid $\left[\mathrm{H}_{2} \mathrm{SO}_{4}\right]$, acetic acid $\left[\mathrm{CH}_{3} \mathrm{COOH}\right]$ and formic acid $\left[\mathrm{CH}_{2} \mathrm{O}_{2}\right]$ ) to eliminate mineral compounds (calcium carbonate $\left[\mathrm{CaCO}_{3}\right]$ and calcium phosphate $\left[\mathrm{Ca}_{3}\left[\mathrm{PO}_{4}\right]_{2}\right]$ ); for deproteinization, an alkaline treatment is used where proteins are eliminated with (sodium hydroxide $[\mathrm{NaOH}]$ ); in discoloration, if a colorless product is 
expected, organic or inorganic solvents (acetone, sodium hypochlorite and hydrogen peroxide) are used to eliminate pigments (astaxanthin and $\beta$-carotene) (Santos et al., 2020).

Chitosan is described according to the degree of deacetylation and molecular weight. The degree of deacetylation establishes the content of free amino groups and allows differentiating chitin from chitosan (Taşkın et al., 2014). In general, the greater deacetylation degree, the greater solubility in acid conditions, positive charge, thus, antimicrobial activity (Tolaimate et al., 2003). Chitosan is classified according to its molecular weight in high (>300 kDa)-medium (> $190 \mathrm{kDa}$ up to $300 \mathrm{kDa})$-or low (>16 kDa up to $190 \mathrm{kDa}$ )molecular-weight and oligochitosan $(\leq 16 \mathrm{kDa})$ (Verlee et al., 2017). High and medium-molecular-weight chitosan coats the cell surface, blocking nutrient transport to the microbial cellular membrane and causing cell lysis (Li et al., 2010). Low-molecular-weight chitosan and oligochitosan go through cellular membranes of microorganisms, bind to DNA, and inhibit RNAm synthesis (Chien et al., 2016). Moreover, oligochitosan produces changes in internal cell structure causing cell lysis and releasing intercellular components (Kulikov et al., 2014). The main difference between chitin and chitosan is the content in amino groups and their physicalchemical properties related with flocculation, chelation and biological functions (Xia et al., 2011). Chitosan in addition to organic acids, such as formic, ascetic, ascorbic acids forms chitosonium acids salts and turns soluble in water, which confers greater versatility when compared to chitin (Vinsova and Vavrikova, 2008; Philibert et al., 2017).

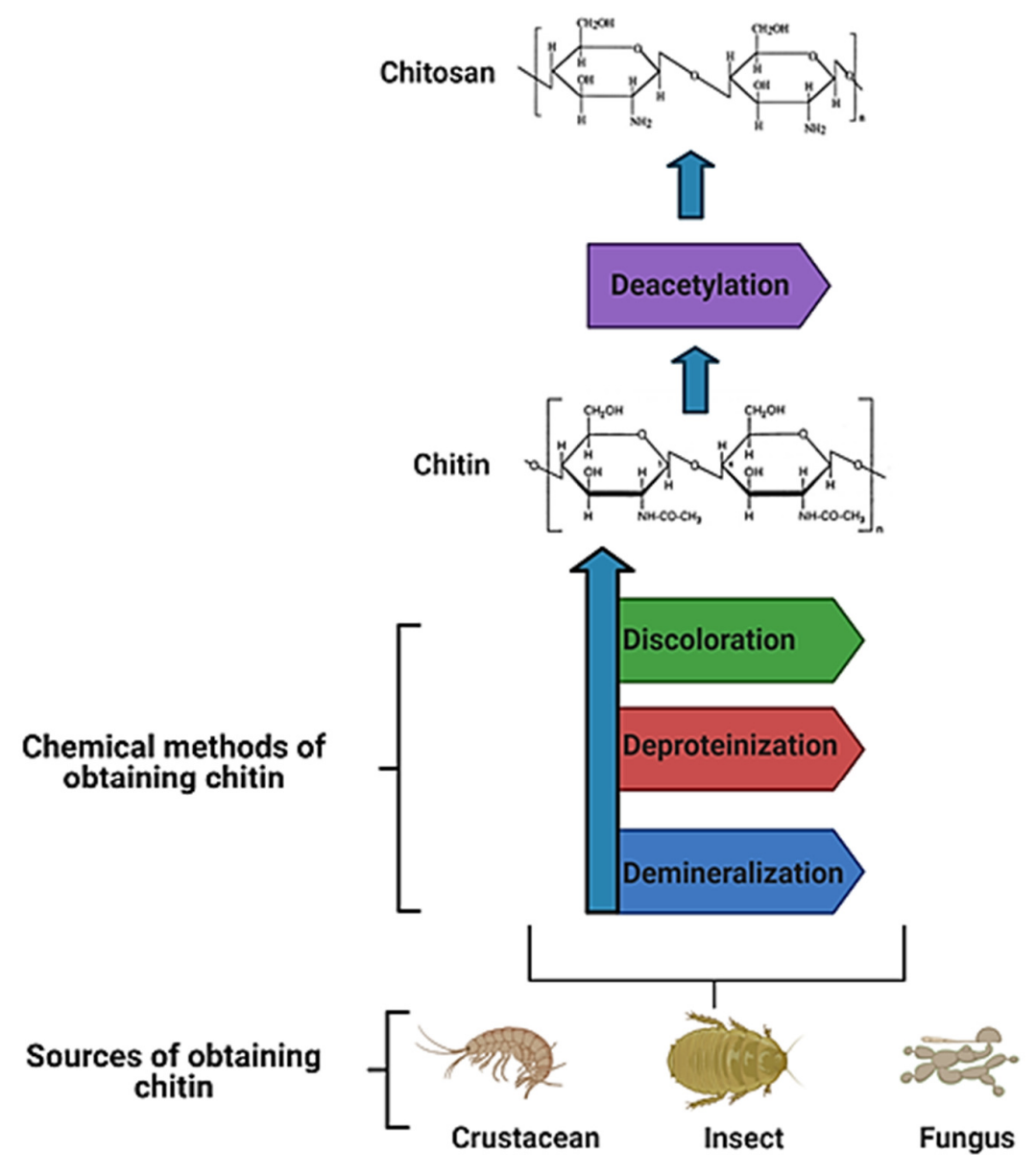

Figure 1. Chemical method of obtaining chitin Source: Authors 


\section{Chitosan antimicrobial properties}

Chitosan antimicrobial activity depends on the type of microorganism, molecular weight, deacetylation degree, besides inoculant concentration, temperature, culture medium, $\mathrm{pH}$, among others (Wang et al., 2020b). The types of microorganisms sensitive to chitosan are grouped into Gram-positive and Gram-negative bacteria, sensitive and resistant fungi (Palma-Guerrero et al., 2010).

Chitosan interacts with the cell surface of microorganisms, which leads to affectations in cell membrane permeabilization (Wang et al., 2015). This interaction is mainly electrostatic because of the presence of amino $\left(\mathrm{NH}^{3+}\right)$ glucosamine groups and their capacity to interact with surface components with a negative charge and many microorganisms (lipopolysaccharides in Gram-negative bacteria, teichoic acid in Gram-positive bacteria and cell membrane phospholipids in fungi). These interactions cause extensive alterations in cell surface, which leads to integral cell wall and membrane loss, release of intracellular material and cell death (Ma et al., 2017) (Figure 2).

Chitosan also has antimicrobial activity by chelation of essential nutrients and metals (zinc [ $\mathrm{Zn}]$, copper $[\mathrm{Cu}]$, cobalt [Co], manganese [Mn], nickel [Ni] and cadmium [Cd]) (Divya et al., 2017). Wang et al. (2004), demonstrated that when $\mathrm{Zn}$ ions were chelated, the positive charge strengthened in the chitosan amino group, increasing its capacity to interact with cell surface components of the microorganisms. Furthermore, chitosan (especially low-molecular-weight) causes damage in ribosomes and DNA; it penetrate the cell wall of microorganisms and bind to DNA, inhibiting DNA/RNA synthesis and protein translation (Schelegueda et al., 2016). Moreover, chitosan forms a layer in cell surface that avoids nutrient entrance (Liu et al., 2004).
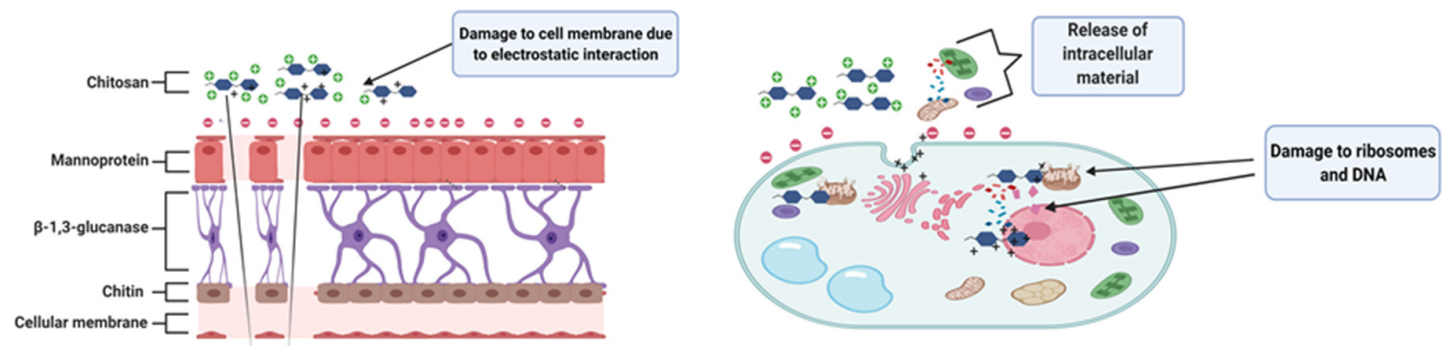

Figure 2. Chitosan antimicrobial activity in cells

Source: Authors

\section{Chitosan effect on phytopathogenic fungi}

Chitosan is efficient in inhibiting spore germination, germinal tube and mycelium elongation of phytopathogenic fungi. Chitosan antifungal mechanism implies alteration and rupture of the cell wall that interferes directly on phytopathogen growth (Chun and Chandrasekaran, 2019). Permeabilization of the phytopathogen plasmatic membranes by chitosan depends on fluidity; the membranes of sensitive fungi to chitosan are rich in polyunsaturated fatty acids (PUFA) (linoleic acid), so they are very fluid (Palma-Guerrero et al., 2010) (Table 2).

Resistant fungi have low-fluidity membranes enriched with saturated fatty acids (SFA) (palmitic or stearic) (Palma-Guerrero et al., 2010). Lopez-Moya et al. (2015), demonstrated that chitosan permeabilized Neurospora crassa cell membrane, which triggered intracellular production of ROS and cell death; intracellular ROS production oxidizes PUFA of cell membranes, permeabilizing the plasmatic membrane and causing cell lysis. 
Table 2. Chitosan effects on phytopathogenic fungi

\begin{tabular}{|c|c|c|c|c|c|}
\hline Chitosan ${ }^{\S^{*}}$ & $\begin{array}{c}\mathrm{Mw} \\
(\mathrm{kDa})^{¥}\end{array}$ & $\begin{array}{l}\mathrm{DD} \\
(\%)^{\ell}\end{array}$ & $\begin{array}{l}\text { Phytopathogenic } \\
\text { fungi }\end{array}$ & Biological effect & Reference \\
\hline $5 \mathrm{mg} \mathrm{mL}^{-1}$ & 350 & 90 & $\begin{array}{l}\text { Penicillium } \\
\text { expansum }\end{array}$ & $\begin{array}{c}\text { Alteration of plasma membrane; } \\
\text { pleomorphic and anamorphic spores }\end{array}$ & Wang et al., 2014 \\
\hline $0.1 \%$ & 100 & 93 & $\begin{array}{l}\text { Aspergillus } \\
\text { ochraceus }\end{array}$ & $\begin{array}{l}\text { Wilting, abnormal branching, and } \\
\text { vacuolation in hyphae }\end{array}$ & Meng et al., 2020 \\
\hline $5 \mathrm{mg} \mathrm{mL}^{-1}$ & $\begin{array}{c}\text { not } \\
\text { specified }\end{array}$ & 85 & Fusarium andiyazi & $\begin{array}{l}\text { Membrane rupture and leakage of } \\
\text { cellular components }\end{array}$ & $\begin{array}{c}\text { Chun and } \\
\text { Chandrasekaran, } \\
2019\end{array}$ \\
\hline $1.25 \mathrm{~g} \mathrm{~L}^{-1}$ & 350 & 90 & $\begin{array}{l}\text { Alternaria } \\
\text { tenuissima }\end{array}$ & Damage to plasma membrane & Liu et al., 2019 \\
\hline $2.5 \mathrm{mg} \mathrm{mL}^{-1}$ & 50 & 90 & Botryosphaeriasp. & Mycelial growth inhibition & Wang et al., 2017 \\
\hline $0.32 \%$ & $\begin{array}{c}\text { not } \\
\text { specified }\end{array}$ & 90 & $\begin{array}{l}\text { Colletotrichum } \\
\text { capsici }\end{array}$ & $\begin{array}{l}\text { Mycelial growth inhibition and } \\
\text { germination of conidia }\end{array}$ & Long et al., 2018 \\
\hline $8 \mathrm{mg} \mathrm{mL}^{-1}$ & $\begin{array}{c}\text { not } \\
\text { specified }\end{array}$ & 88 & $\begin{array}{l}\text { Fusarium } \\
\text { oxysporum f. sp. } \\
\text { cubense }\end{array}$ & $\begin{array}{l}\text { Agglomeration of hyphae, abnormal } \\
\text { forms, vesicles, or empty cells devoid } \\
\text { of cytoplasm in the mycelium }\end{array}$ & $\begin{array}{l}\text { Al-Hetar et al., } \\
\quad 2011\end{array}$ \\
\hline
\end{tabular}

\section{Chitosan effect in plants}

\section{Resistance inductor}

Plant resistance is activated by a great number of inductors biotic (fungi, bacteria, virus, phytoplasma and insects) and abiotic (chemical and physical) known as induced resistance (Meena et al., 2020a). Two types of induced resistance are known -systemic acquired resistance (SAR) and induced systemic resistance (ISR)mediated by phytohormones, such as salicylic acid (SA), jasmonic acid (JA), and ethylene (ET) (Malerba and Cerana, 2016). SAR depends on SA signal molecule and ISR depends on JA and ET (Vlot et al., 2020).

The first line of recognition in plants toward phytopathogens is through pattern recognition receptors (PRR), which recognize microbial compounds, such as bacterial flagellum or fungal chitin - called by pathogenassociated molecular pattern (PAMP), microbe-associated molecular pattern (MAMP), or damage-associated molecular patterns (DAMPs) (Mauch-Mani et al., 2017). Pattern recognition translates in first line of defense called activated immunity by PAMP or PAMP-triggered immunity (PTI) (Bigeard et al., 2015). Chitosan behaves as a general elicitor, inducing resistance by a mediated PRR recognition (Lopez-Moya et al., 2019). The defense responses caused by chitosan include an increase of cytosolic $\mathrm{Ca}^{2+}$, callose deposition, oxidative explosion, hypersensitive response (HR), abscisic acid (ABA), ET, JA, SA, enzymes related with defense, phytoalexins, and PR protein (Gai et al., 2019; de Lamo et al., 2020; Dubin et al., 2021) (Figure 3).

Chitin recognition by plants is associated to proteins (CEBiP/CERK), but chitosan lacks specific receptors (Yin et al., 2016). Thus, chitosan is a molecular pattern associated to less efficient phytopathogens than chitin (Lopez-Moya et al., 2019). 


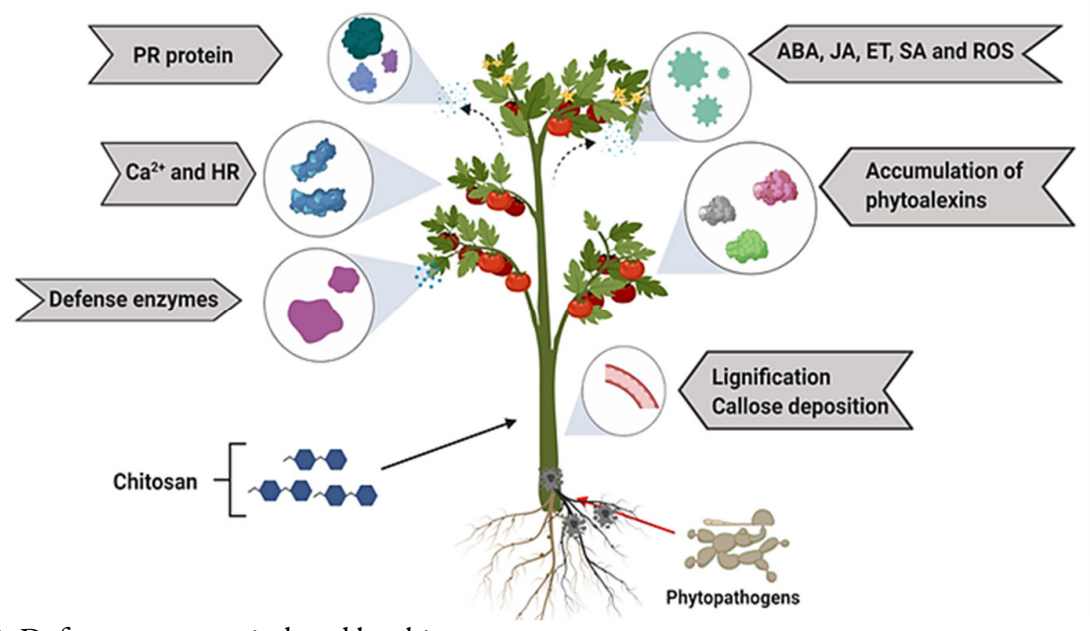

Figure 3. Defense responses induced by chitosan

Source: Authors

\section{Proteins related with pathogenicity}

Chitosan in plants induces protein production related with pathogenesis with antimicrobial activity to protect itself from phytopathogens (Liu et al., 2019). An example of these proteins related to pathogenesis are chitinase and $\beta$-1,3-glucanase (Hadwiger, 2013). The cell wall is responsible for cell physical integrity, and in the case of fungi, it is formed by chitin layers and $\beta$-1,3-glucan (Spadaro and Droby, 2016); $\beta$-1,3-glucan hydrolyzes $\beta$-D-glycoside bonds of $\beta$-1,3-glucan; chitinases hydrolyze $\beta-1,4$ bonds of $N$-acetyl $\beta$-D-glucosamine obtained from chitin, breaking phytopathogen cell walls (Kaur et al., 2005).

Chitosan activates a subset of genes (PR-genes), which are called genes related to pathogenicity that cause disease resistance (Dubin et al., 2021). Chitosan increases transcription of these genes by activating cell or membrane receptor surface by the plant DNA interaction, which in turn influences on genetic transcription (Hadwiger, 2013). In general, chitosan direct interactions with DNA influence gene transcription related to pathogenicity and PR protein synthesis (Loschke et al., 1983).

\section{Enzymes related with defense}

The actions of enzymes related to plant defense, such as polyphenol, phenylalanine ammonia lyase, catalase, peroxidase and superoxide dismutase, increase with chitosan application, inducing plant resistance against phytopathogens (Gutiérrez-Martínez et al., 2017).

Polyphenol oxidase catalyzes phenolic substances to synthesize lignin, strengthen cell wall structure and avoid entrance and colonization of phytopathogens toward plants (Avdiushko et al., 1993). Moreover, catalyzes oxidation of phenolic compounds to quinone (antimicrobial compounds), which are toxic for phytopathogens (Soliva et al., 2000). Phenylalanine ammonia-lyase is important in phenylpropanoid pathway and catalyzes L-phenylalanine conversion into trans-cinnamic acid (Bhattacharyya and Ward, 1988).

Phenylalanine ammonia-lyase products are modified through phenylpropanoid metabolism to secondary metabolites (lignin, flavonoids, and phytoalexins), which are important in plant resistance against phytopathogens (Morrison and Buxton, 1993). Catalase is the main enzyme for eliminating hydrogen peroxide $\left(\mathrm{H}_{2} \mathrm{O}_{2}\right)$ in microorganisms, implied in $\mathrm{H}_{2} \mathrm{O}_{2}$ in $\mathrm{H}_{2} \mathrm{O}$ and $\mathrm{O}_{2}$ degradation (Yang and Poovaiah, 2002). Peroxidase is an enzyme that catalyzes ROS oxidation, such as $\mathrm{H}_{2} \mathrm{O}_{2}$ that has antifungal activity facing diverse phytopathogens and participates in various physiological processes, such as lignification, suberization and auxin catabolism (Hiraga et al., 2001). Superoxide dismutase is responsible for eliminating ROS species to protect plants from oxidative stress during phytopathogen invasion (Lamb and Dixon, 1997). 


\section{Phytoalexins}

Phytoalexins are low-molecular-weight compounds with antimicrobial properties, which are synthesized in low concentrations when plants are healthy but accumulate in great concentrations in response to a phytopathogen or an exogenous inductor (Keen and Bruegger, 1977). Phytoalexins are toxic and inhibit germ tube elongation and growth, decrease mycelial growth, and limit glucose absorption in fungi (Hammerschmidt, 1999). They are specific plants for each family with different chemical structures and synthesized by different enzymes, which make their mechanisms of action complex to study (Shamshina et al., 2020). Some phytoalexins synthesized by treated plants with chitosan are type formononetin, calicosine, phenylpropanoid and triterpenoid (Lucini et al., 2018; Gai et al., 2019).

\section{Lignin}

Lignin -jointly with cellulose and hemicellulose- contributes to hardening plant cell wall (Rajan et al., 2005). The lignification of cell walls is a mechanism of plant resistance to phytopathogens. Moreover, chitosan application forms a physical barrier in plants, which avoids phytopathogen entrance and colonization (Liu et al., 2019). Furthermore, $P R$ protein accumulation and ROS stimulation as $\mathrm{H}_{2} \mathrm{O}_{2}$ by the effect of adding chitosan, induce the formation of phenolic compounds, such as phytoalexins that promote lignification (Chun and Chandrasekaran, 2019).

\section{Callose}

Callose deposition is a plant reaction to biotic and abiotic stress, such as lesions and infection caused by phytopathogens; it also isolates stress impact in the tissue locally by depositing a physical barrier (Farrokhi et al., 2006). Chitosan application promotes an increase of $\mathrm{Ca}^{2+}$ concentrations (Zuppini et al., 2004) and induces callose deposition in plants (Luna et al., 2011). Callose synthesis is correlated with an increase in $\mathrm{Ca}^{2+}$ net absorption by cells; $\mathrm{Ca}^{2+}$ has access to the cytoplasm and act as a second messenger capable of directly activating $\beta$-1-3-glucan synthase located in the plasmatic membrane and dependent on $\mathrm{Ca}^{2+}$, making callose deposition locally (Waldmann et al., 1988).

\section{Chitosan molecular recognition}

In Arabidopsis sp. kinase 1 (CERK1) chitin receptor has demonstrated to be fundamental in molecular pattern recognition associated to phytopathogens (Miya et al., 2007). The affinity of a specific protein (lectin) for glucosamine oligomers has been demonstrated by chitosan affinity chromatography, starting from Rubus fruticosus L. cultured cells. Lectine is a receptor of oligomers derived from chitosan with defense response inductor activity against phytopathogens (Liénart et al., 1991).

Chitosan binding proteins are determined in tobacco crop and Arabidopsis sp. plasmatic membrane (Yin et al., 2009; Yin et al., 2016). Tobacco protein is $75 \mathrm{kDa}$, similar to CERK1 chitin receptor. Nevertheless, the studies that have been performed are not sufficient to determine whether it is a receptor or not. Furthermore, Arabidopsis sp. protein is small (12 kDa), which suggests it is not a receptor (Yin et al., 2016).

Additionally, chitosan interaction has been demonstrated marked with fluorescence with wheat leaves and chitosan interaction with plasmatic membrane proteins, such as W5G2U8_WHEAT (a potential kinase receptor protein associated to the wall), W5HY42_WHEAT, and W5I0R4_WHEAT (serine/threonineprotein kinase similar to lectin receptor $S$ type G) as potential chitosan receptors (Liu et al., 2018). Another point of view proposed that chitosan does not have plant specific receptors. Chitosan cationic properties have been established to allow plant plasma membrane binding.

However, another cation-oligomer material (poly-L-lysine) does not inhibit chitosan binding to colza membrane; thus, the bond does not depend only on cationic property (Yin et al., 2013). Chitosan structural complexity makes its understanding difficult, which is why chitosan receptor in plants has not been clarified yet (Li et al., 2020). 


\section{Chitosan effect on fruit protection against phytopathogens}

Postharvest diseases are the main cause of fruit loss, which tend to have short shelf life (Ye et al., 2021). The adhesive nature of chitosan, its biodegradability, and antifungal activity make chitosan coating application an option to extend fruit shelf life (Wang et al., 2020a).

Chitosan coating form a semipermeable film in fruit surface, minimizing respiration rate, decreasing water loss and weight, and extending fruit quality attributes effectively (Table 3) (Silva et al., 2018). Furthermore, chitosan coating helps to avoid phytopathogen colonization (Gutiérrez-Martínez et al., 2017).

Table 3. Chitosan effects on fruits

\begin{tabular}{|c|c|c|c|c|c|}
\hline Chitosan ${ }^{\S^{*}}$ & $\begin{array}{c}\mathrm{Mw} \\
(\mathrm{kDa})^{¥}\end{array}$ & $\begin{array}{l}\mathrm{DD} \\
(\%)^{\ell}\end{array}$ & Fruit & Biological effect & Reference \\
\hline $3 \%$ & $\begin{array}{c}\text { not } \\
\text { specified }\end{array}$ & 98 & Guava & $\begin{array}{l}\text { Breathing, fresh weight loss, } \\
\text { firmness, color and antioxidant } \\
\text { activity }\end{array}$ & Silva et al., 2018 \\
\hline $1 \%$ & 360 & 85 & Mango & Fruit ripening and weight loss & Jongsri et al., 2016 \\
\hline $1 \%$ & 17.4 & $75-85$ & $\begin{array}{l}\text { Soursop, } \\
\text { mango, } \\
\text { banana }\end{array}$ & Firmness and weight loss & $\begin{array}{c}\text { Gutiérrez-Martínez } \\
\text { et al., } 2017\end{array}$ \\
\hline $1.5 \%$ & $\begin{array}{c}\text { not } \\
\text { specified }\end{array}$ & $\begin{array}{c}\text { not } \\
\text { specified }\end{array}$ & Strawberry & Fruit softening & Wang et al., 2020a \\
\hline $1.9 \mathrm{mg} \mathrm{mL}^{-1}$ & 50 & 90 & Pear & $\begin{array}{l}\text { Fruit decomposition, defense } \\
\text { enzymes, nutritional value, and } \\
\text { weight loss }\end{array}$ & Wang et al., 2017 \\
\hline $1 \%$ & 360 & 85 & Mango & $\begin{array}{l}\text { Fruit softening, accumulation of } \\
\text { phenolic compounds and defense } \\
\text { enzymes }\end{array}$ & Jongsri et al., 2017 \\
\hline $1 \%$ & $\begin{array}{c}\text { not } \\
\text { specified }\end{array}$ & $\begin{array}{c}\text { not } \\
\text { specified }\end{array}$ & Jujube & $\begin{array}{l}\text { Fruit senescence, nutrient and } \\
\text { antioxidant content }\end{array}$ & Kou et al., 2017 \\
\hline
\end{tabular}

${ }^{*}={ }^{\S}$ Chitosan concentration, ${ }^{¥}$ Molecular weight, ${ }^{£}$ Degree of deacetylation

\section{Chitosan nanoparticles in agriculture}

Chitosan nanoparticles (CNP) are being used in agriculture to promote plant growth (Chun and Chandrasekaran, 2019). Their main effects against phytopathogens are related with antimicrobial activity (Sathiyabama and Parthasarathy, 2016; Varamin et al., 2020). Moreover, CNP treatment improves plant immune response, increasing the activity of enzymes related with PR protein defense, as well as raising total phenol levels (Chandra et al., 2015). Furthermore, CNP are used as nano-porters; nano-encapsulation increases bioavailability, solubility, and retention time of bioactive compounds (Muthukrishnan et al., 2019).

A recent study demonstrated that CNP inhibited Pyricularia grisea, A. solani, F. oxysporum growth in vitro, and chickpea seeds treated with CNP have a greater germination percentage, seed vigor index, and vegetative seedling biomass (Sathiyabama and Parthasarathy, 2016). Abdel-Aliem et al. (2019), demonstrated CNP antifungal effects against A. tenuis, Beauveria bassiana, F. graminearum, F. oxysporum, A. niger, A. flavus, Penicillium sp. and Sclerotium rolfsii. CNP also inhited mycelial growth in C. gloeosporioides, Phytophthora capsici, S. sclerotiorum, F. oxysporum and Gibberella fujikuroi (Oh et al., 2019). Additionally, the use of copper nanoparticles coupled to chitosan inhibited Rhizoctonia solani and Pythium aphanidermatum causal agent of damping-off disease (Vanti et al., 2020).

CNP application charged with thiamine in chickpea seedlings improved germination index, growth and improved production of indole ascetic acid when compared with non-treated seedlings (Muthukrishnan et al., 
2019). Salicylic acid nanoparticles and chitosan increased the production of defense antioxidant enzymes, improving ROS equilibrium, increasing lignin deposition in cell wall, improving growth and disease control in maize (Kumaraswamy et al., 2019). CNP in tomato crop induced PR protein expression (PR-1, PR-2, PR-8, and PR-10) and controlled wilting disease produced by F. andiyazi (Chun and Chandrasekaran, 2019).

\section{Conclusions}

From the ecological point of view, chitosan constitutes an option for agriculture since it does not pollute the environment and is not harmful for human health. Chitosan is important to control phytopathogens that colonize plants, generating a struggle between plant immunity and fungus virulence. Chitosan activates plant defense increasing callose deposition, production of enzymes related to defense, phytoalexins and proteins. Furthermore, chitosan application improves growth, development, and yield parameters in numerous crops. A great number of recently published articles testify the interest of scientists for the use of this biopolymer in agriculture, which lead to an extension of its use and benefits for the environment.

\section{Authors' Contributions}

Conceptualization: LGHM, JJRP, JATR; Methodology: LGHM, JJRP, JATR; Project administration: LGHM; Validation: CA, TRC, EQA; Writing: LGHM, JJRP, JATR; Review and editing: LGHM, JJRP, CA, TRC. All authors read and approved the final manuscript.

\section{Acknowledgements}

The first author is grateful to Consejo Nacional de Ciencia y Tecnología (CONACYT), Mexico for Grant No. 2021910046 to carry out the Doctoral thesis project. The authors are grateful to Diana Fischer for editorial services in English.

\section{Conflict of Interests}

The authors declare that there are no conflicts of interest related to this article.

\section{References}

Abdel-Aliem HA, Gibriel AY, Rasmy NM, Sahab AF, El-Nekeety AA, Abdel-Wahhab MA (2019). Antifungal efficacy of chitosan nanoparticles against phytopathogenic fungi and inhibition of zearalenone production by Fusarium graminearum. Comunicata Scientiae 10(3):338-345. https://doi.org/10.14295/cs.v10i3.1899

Ahsan SM, Thomas M, Reddy KK, Sooraparaju SG, Asthana A, Bhatnagar I (2018). Chitosan as biomaterial in drug delivery and tissue engineering. International Journal of Biological Macromolecules 110:97-109. https://doi.org/10.1016/j.ijbiomac.2017.08.140

Aili D, Adour L, Houali K, Amrane A (2019). Effect of temperature in chitin and chitosan production by solid culture of Penicillium Camembertii on YPG medium. International Journal of Biological Macromolecules 133:998-1007. https://doi.org/10.1016/j.ijbiomac.2019.04.116 
Al-Hetar MY, Zainal Abidin MA, Sariah M, Wong MY (2011). Antifungal activity of chitosan against Fusarium oxysporum f. sp. cubense. Journal of Applied Polymer Science 120(4):2434-2439. https://doi.org/10.1002/app.33455

Aranaz I, Acosta N, Civera C, Elorza B, Mingo J, Castro C, ... Heras Caballero A (2018). Cosmetics and cosmeceutical applications of chitin, chitosan and their derivatives. Polymers 10(2):213. https://doi.org/10.3390/polym10020213

Avdiushko SA, Ye XS, Kuc J (1993). Detection of several enzymatic activities in leaf prints of cucumber plants. Physiological and Molecular Plant Pathology 42(6):441-454. https://doi.org/10.1006/pmpp.1993.1033

Baker BP, Green TA, Loker AJ (2020). Biological control and integrated pest management in organic and conventional systems. Biological Control 140:104095. https://doi.org/10.1016/j.biocontrol.2019.104095

Berger LRR, Stamford NP, Willadino LG, Laranjeira D, de Lima MAB, Malheiros SMM, ... Stamford TCM (2016). Cowpea resistance induced against Fusarium oxysporum f. sp. tracheiphilum by crustaceous chitosan and by biomass and chitosan obtained from Cunninghamella elegans. Biological Control 92:45-54. https://doi.org/10.1016/j.biocontrol.2015.09.006

Bhattacharyya MK, Ward EWB (1988). Phenylalanine ammonia-lyase activity in soybean hypocotyls and leaves following infection with Phytophthora megasperma f. sp. glycinea. Canadian Journal of Botany 66(1):18-23. https://doi.org/10.1139/b88-003

Bigeard J, Colcombet J, Hirt H (2015). Signaling mechanisms in pattern-triggered immunity (PTI). Molecular Plant 8(4):521-539. https://doi.org/10.1016/j.molp.2014.12.022

Chandra S, Chakraborty N, Dasgupta A, Sarkar J, Panda K, Acharya K (2015). Chitosan nanoparticles: a positive modulator of innate immune responses in plants. Scientific Reports 5:15195. https://doi.org/10.1038/srep15195

Chang AKT, Frias Jr RR, Alvarez LV, Bigol UG, Guzman JPMD (2019). Comparative antibacterial activity of commercial chitosan and chitosan extracted from Auricularia sp. Biocatalysis and Agricultural Biotechnology 17:189-195. https://doi.org/10.1016/j.bcab.2018.11.016

Cheba BA (2011). Chitin and chitosan: marine biopolymers with unique properties and versatile applications. Global Journal of Biotechnology and Biochemistry 6(3):149-153.

Chien RC, Yen MT, Mau JL (2016). Antimicrobial and antitumor activities of chitosan from shiitake stipes, compared to commercial chitosan from crab shells. Carbohydrate Polymers 138:259-264. https://doi.org/10.1016/j.carbpol.2015.11.061

Chun SC, Chandrasekaran M (2019). Chitosan and chitosan nanoparticles induced expression of pathogenesis-related proteins genes enhances biotic stress tolerance in tomato. International Journal of Biological Macromolecules 125:948-954. https://doi.org/10.1016/j.ijbiomac.2018.12.167

Coutinho TC, Ferreira MC, Rosa LH, de Oliveira AM, de Oliveira Júnior EN (2020). Penicillium citrinum and Penicillium mallochii: New phytopathogens of orange fruit and their control using chitosan. Carbohydrate Polymers 234:115918. https://doi.org/10.1016/j.carbpol.2020.115918

de Lamo FJ, Šimkovicová M, Fresno DH, de Groot T, Tintor N, Rep M ... Takken FL (2020). Pattern-triggered immunity restricts host colonization by endophytic fusaria, but does not affect endophyte-mediated resistance. Molecular Plant Pathology 00:1-12. https://doi.org/10.1111/mpp.13018

Divya K, Vijayan S, George TK, Jisha MS (2017). Antimicrobial properties of chitosan nanoparticles: Mode of action and factors affecting activity. Fibers and Polymers 18(2):221-230.

Dubin A, Likhanov A, Klyachenko O, Subin A, Kluvadenko A (2021). Effect of chitosan formulations of different biological origin on tobacco (Nicotiana tabacum L.) PR-genes expression. Journal of Microbiology, Biotechnology and Food Sciences 9(6):1141-1144. https://doi.org/10.15414/jmbfs.2020.9.6.1141-1144

El Amerany F, Meddich A, Wahbi S, Porzel A, Taourirte M, Rhazi M, ... Hause B (2020). Foliar application of chitosan increases tomato growth and influences mycorrhization and expression of endochitinase-encoding genes. International Journal of Molecular Sciences 21(2):535. https://doi.org/10.3390/ijms21020535

Farrokhi N, Burton RA, Brownfield L, Hrmova M, Wilson SM, Bacic A, ... Fincher GB (2006). Plant cell wall biosynthesis: genetic, biochemical and functional genomics approaches to the identification of key genes. Plant Biotechnology Journal 4(2):145-167. https://doi.org/10.1111/j.1467-7652.2005.00169.x

Fournier P, Szczepanski CR, Godeau RP, Godeau G (2020). Chitosan extraction from Goliathus orientalis Moser, 1909: Characterization and comparison with commercially available chitosan. Biomimetics 5(2):15. https://doi.org/10.3390/biomimetics5020015 
Gai QY, Jiao J, Wang X, Liu J, Wang Z, Fu YJ (2019). Chitosan promoting formononetin and calycosin accumulation in Astragalus membranaceus hairy root cultures via mitogen-activated protein kinase signaling cascades. Scientific Reports 9(1):1-11. https://doi.org/10.1038/s41598-019-46820-6

Gutiérrez-Martínez P, Bautista-Baños S, Berúmen-Varela G, Ramos-Guerrero A, Hernández-Ibañez AM (2017). In vitro response of Colletotrichum to chitosan. Effect on incidence and quality on tropical fruit. Enzymatic expression in mango. Acta Agronómica 66(2):282-289. http://dx.doi.org/10.15446/acag.v66n2.53770

Hadwiger LA (2013). Multiple effects of chitosan on plant systems: solid science or hype. Plant Science 208:42-49. https://doi.org/10.1016/j.plantsci.2013.03.007

Hamdi M, Hammami A, Hajji S, Jridi M, Nasri M, Nasri R (2017). Chitin extraction from blue crab (Portunus segnis) and shrimp (Penaeus kerathurus) shells using digestive alkaline proteases from P. segnis viscera. International Journal of Biological Macromolecules 101:455-463. https://doi.org/10.1016/j.ijbiomac.2017.02.103

Hamed I, Özogul F, Regenstein JM (2016). Industrial applications of crustacean by-products (chitin, chitosan, and chitooligosaccharides): A review. Trends in Food Science and Technology 48:40-50. https://doi.org/10.1016/j.tifs.2015.11.007

Hammerschmidt R (1999). Phytoalexins: what have we learned after 60 years?. Annual Review of Phytopathology 37(1):285-306. https://doi.org/10.1146/annurev.phyto.37.1.285

Hiraga S, Sasaki K, Ito H, Ohashi Y, Matsui H (2001). A large family of class III plant peroxidases. Plant and Cell Physiology 42(5):462-468. https://doi.org/10.1093/pcp/pce061

Jiang X, Lin H, Lin M, Chen Y, Wang H, Lin Y, ... Lin Y (2018). A novel chitosan formulation treatment induces disease resistance of harvested litchi fruit to Peronophythora litchii in association with ROS metabolism. Food Chemistry 266:299-308. https://doi.org/10.1016/j.foodchem.2018.06.010

Jongsri P, Rojsitthisak P, Wangsomboondee T, Seraypheap K (2017). Influence of chitosan coating combined with spermidine on anthracnose disease and qualities of 'Nam Dok Mai'mango after harvest. Scientia Horticulturae 224:180-187. https://doi.org/10.1016/j.scienta.2017.06.011

Jongsri P, Wangsomboondee T, Rojsitthisak P, Seraypheap K (2016). Effect of molecular weights of chitosan coating on postharvest quality and physicochemical characteristics of mango fruit. LWT-Food Science and Technology 73:28-36. https://doi.org/10.1016/j.lwt.2016.05.038

Katiyar D, Hemantaranjan A, Singh B (2015). Chitosan as a promising natural compound to enhance potential physiological responses in plant: a review. Indian Journal of Plant Physiology 20(1):1-9. https://doi.org/10.1007/s40502-015-0139-6

Kaur J, Munshi GD, Singh RS, Koch E (2005). Effect of carbon source on production of lytic enzymes by the sclerotial parasites Trichoderma atroviride and Coniothyrium minitans. Journal of Phytopathology 153(5):274-279. https://doi.org/10.1111/j.1439-0434.2005.00969.x

Kaya M, Baran T (2015a). Description of a new surface morphology for chitin extracted from wings of cockroach (Periplaneta americana). International Journal of Biological Macromolecules 75:7-12. https://doi.org/10.1016/j.ijbiomac.2015.01.015

Kaya M, Baublys V, Šatkauskienė I, Akyuz B, Bulut E, Tubelytė V (2015b). First chitin extraction from Plumatella repens (Bryozoa) with comparison to chitins of insect and fungal origin. International Journal of Biological Macromolecules 79:126-132. https://doi.org/10.1016/j.ijbiomac.2015.04.066

Keen NT, Bruegger B (1977). Phytoalexins and chemicals that elicit their production in plants. In: Hedin PA (Eds). Host Plant Resistance to Pests. pp 1-26. https://doi.org/10.1021/bk-1977-0062.ch001

Khan MI, An X, Dai L, Li H, Khan A, Ni Y (2019). Chitosan-based polymer matrix for pharmaceutical excipients and drug delivery. Current Medicinal Chemistry 26(14):2502-2513. https://doi.org/10.2174/0929867325666180927100817

Kou X, Li Y, Wu J, Chen Q, Xue Z (2017). Effects of edible coatings on quality and antioxidant activity of Zizyphus jujuba Miller cv. Dongzao during storage. Transactions of Tianjin University 23(1):51-61. https://doi.org/10.1007/s12209-016-0021-2

Kulikov SN, Lisovskaya SA, Zelenikhin PV, Bezrodnykh EA, Shakirova DR, Blagodatskikh IV, ... Tikhonov VE (2014). Antifungal activity of oligochitosans (short chain chitosans) against some Candida species and clinical isolates of Candida albicans: Molecular weight-activity relationship. European Journal of Medicinal Chemistry 74:169178. https://doi.org/10.1016/j.ejmech.2013.12.017 
Kumaraswamy RV, Kumari S, Choudhary RC, Sharma SS, Pal A, Raliya R, ... Saharan V (2019). Salicylic acid functionalized chitosan nanoparticle: a sustainable biostimulant for plant. International Journal of Biological Macromolecules 123:59-69. https://doi.org/10.1016/j.ijbiomac.2018.10.202

Lamb C, Dixon RA (1997). The oxidative burst in plant disease resistance. Annual Review of Plant Biology 48(1):251275. https://doi.org/10.1146/annurev.arplant.48.1.251

Li K, Xing R, Liu S, Li P (2020). Chitin and chitosan fragments responsible for plant elicitor and growth stimulator. Journal of Agricultural and Food Chemistry 68(44):12203-12211. https://doi.org/10.1021/acs.jafc.0c05316

Li LH, Deng JC, Deng HR, Liu ZL, Li XL (2010). Preparation, characterization and antimicrobial activities of chitosan/Ag/ZnO blend films. Chemical Engineering Journal 160(1):378-382. https://doi.org/10.1016/j.cej.2010.03.051

Liénart Y, Gautier C, Domard A (1991). Isolation from Rubus cell-suspension cultures of a lectin specific for glucosamine oligomers. Planta 184(1):8-13. https://doi.org/10.1007/BF00208229

Liu D, Jiao S, Cheng G, Li X, Pei Z, Pei Y, ... Du Y (2018). Identification of chitosan oligosaccharides binding proteins from the plasma membrane of wheat leaf cell. International Journal of Biological Macromolecules 111:10831090. https://doi.org/10.1016/j.ijbiomac.2018.01.113

Liu H, Du Y, Yang J, Zhu H (2004). Structural characterization and antimicrobial activity of chitosan/betaine derivative complex. Carbohydrate Polymers 55(3):291-297. https://doi.org/10.1016/j.carbpol.2003.10.001

Liu J, Zhang X, Kennedy J, Jiang M, Cai Q, Wu X (2019). Chitosan induces resistance to tuber rot in stored potato caused by Alternaria tenuissima. International Journal of Biological Macromolecules 140:851-857. https://doi.org/10.1016/j.ijbiomac.2019.08.227

Long L, Tan L, Boi V, Trung T (2018). Antifungal activity of water-soluble chitosan against Colletotrichum capsici in postharvest chili pepper. Journal of Food Processing and Preservation 42(1):e13339. https://doi.org/10.1111/jfpp.13339

Lopez-Moya F, Suarez-Fernandez M, Lopez-Llorca LV (2019). Molecular mechanisms of chitosan interactions with fungi and plants. International Journal of Molecular Sciences 20(2):332. https://doi.org/10.3390/ijms20020332

López-Corona B, Mondaca-Fernández I, Gortáres-Moroyoqui P, Meza-Montenegro M, Balderas-Cortés J, Ruíz Alvarado C, ... Rueda-Puente E (2020). Ecofisiología y bioquímica de Salicornia bigelovii (Torr.) por efecto de quitosanoaib bajo condiciones del desierto de Sonora. Polibotánica 49:75-92. https://doi.org/10.18387/polibotanica.49.5

Lopez-Moya F, Colom-Valiente MF, Martinez-Peinado P, Martinez-Lopez JE, Puelles E, Sempere-Ortells JM, ... LopezLlorca LV (2015). Carbon and nitrogen limitation increase chitosan antifungal activity in Neurospora crassa and fungal human pathogens. Fungal Biology 119(2-3):154-169. https://doi.org/10.1016/j.funbio.2014.12.003

Loschke DC, Hadwiger LA, Wagoner W (1983). Comparison of mRNA populations coding for phenylalanine ammonia lyase and other peptides from pea tissue treated with biotic and abiotic phytoalexin inducers. Physiological Plant Pathology 23(1):163-173. https://doi.org/10.1016/0048-4059(83)90043-7

Lucini L, Baccolo G, Rouphael Y, Colla G, Bavaresco L, Trevisan M (2018). Chitosan treatment elicited defence mechanisms, pentacyclic triterpenoids and stilbene accumulation in grape (Vitis vinifera L.) bunches. Phytochemistry 156:1-8. https://doi.org/10.1016/j.phytochem.2018.08.011

Luna E, Pastor V, Robert J, Flors V, Mauch-Mani B, Ton J (2011). Callose deposition: a multifaceted plant defense response. Molecular Plant-Microbe Interactions 24(2):183-193. https://doi.org/10.1094/MPMI-07-10-0149

Luo Q, Wang Y, Han Q, Ji L, Zhang H, Fei Z, ... Wang Y (2019). Comparison of the physicochemical, rheological, and morphologic properties of chitosan from four insects. Carbohydrate Polymers 209: 266-275. https://doi.org/10.1016/j.carbpol.2019.01.030

Ma Z, Garrido-Maestu A, Jeong KC (2017). Application, mode of action, and in vivo activity of chitosan and its microand nanoparticles as antimicrobial agents: A review. Carbohydrate Polymers 176:257-265. https://doi.org/10.1016/j.carbpol.2017.08.082

Machałowski T, Wysokowski M, Tsurkan MV, Galli R, Schimpf C, Rafaja D, ... Ehrlich H (2019). Spider chitin: an ultrafast microwave-assisted method for chitin isolation from Caribena versicolor spider molt cuticle. Molecules 24(20):3736. https://doi.org/10.3390/molecules 24203736

Malerba M, Cerana R (2016). Chitosan effects on plant systems. International Journal of Molecular Sciences 17(7):996. https://doi.org/10.3390/ijms17070996

Malerba M, Cerana R (2018). Recent advances of chitosan applications in plants. Polymers 10(2):118. https://doi.org/10.3390/polym10020118 
Massi F, Torriani S, Borghi L, Toffolatti S (2021). Fungicide resistance evolution and detection in plant pathogens: Plasmopara viticola as a Case Study. Microorganisms 9(1):119. https://doi.org/10.3390/microorganims9010119

Mauch-Mani B, Baccelli I, Luna E, Flors V (2017). Defense priming: an adaptive part of induced resistance. Annual Review of Plant Biology 68:485-512. https://doi.org/10.1146/annurev-arplant-042916-041132

Meena M, Swapnil P, Divyanshu K, Kumar S, Tripathi YN, Zehra A, ... Upadhyay R (2020a). PGPR-mediated induction of systemic resistance and physiochemical alterations in plants against the pathogens: Current perspectives. Journal of Basic Microbiology 60(10):828-861. https://doi.org/10.1002/jobm.202000370

Meena RS, Kumar S, Datta R, Lal R, Vijayakumar V, Brtnicky M, ... Marfo TD (2020b). Impact of agrochemicals on soil microbiota and management: A review. Land 9(2):34. https://doi.org/10.3390/land9020034

Meng D, Garba B, Ren Y, Yao M, Xia X, Li M, ... Wang Y (2020). Antifungal activity of chitosan against Aspergillus ochraceus and its possible mechanisms of action. International Journal of Biological Macromolecules 158:10631070. https://doi.org/10.1016/j.ijbiomac.2020.04.213

Miya A, Albert P, Shinya T, Desaki Y, Ichimura K, Shirasu K, ... Shibuya N (2007). CERK1, a LysM receptor kinase, is essential for chitin elicitor signaling in Arabidopsis. Proceedings of the National Academy of Sciences 104(49):19613-19618. https://doi.org/10.1073/pnas.0705147104

Morin-Crini N, Lichtfouse E, Torri G, Crini G (2019). Applications of chitosan in food, pharmaceuticals, medicine, cosmetics, agriculture, textiles, pulp and paper, biotechnology, and environmental chemistry. Environmental Chemistry Letters 17(4):1667-1692. https://doi.org/10.1007/s10311-019-00904-X

Morrison TA, Buxton DR (1993). Activity of phenylalanine ammonialyase, tyrosine ammonia-lyase, and cinnamyl alcohol dehydrogenase in the maize stalks. Crop Science 33(6):1264-1268. https://doi.org/10.2135/cropsci1993.0011183X003300060030X

Muthukrishnan S, Murugan I, Selvaraj M (2019). Chitosan nanoparticles loaded with thiamine stimulate growth and enhances protection against wilt disease in Chickpea. Carbohydrate Polymers 212:169-177. https://doi.org/10.1016/j.carbpol.2019.02.037

Obianom C, Romanazzi G, Sivakumar D (2019). Effects of chitosan treatment on avocado postharvest diseases and expression of phenylalanine ammonia-lyase, chitinase and lipoxygenase genes. Postharvest Biology and Technology 147:214-221. https://doi.org/10.1016/j.postharvbio.2018.10.004

Oh JW, Chun SC, Chandrasekaran M (2019). Preparation and in vitro characterization of chitosan nanoparticles and their broad-spectrum antifungal action compared to antibacterial activities against phytopathogens of tomato. Agronomy 9(1):21. https://doi.org/10.3390/agronomy9010021

Palma-Guerrero J, Lopez-Jimenez JA, Pérez-Berná AJ, Huang IC, Jansson HB, Salinas J, ... Lopez-Llorca LV (2010). Membrane fluidity determines sensitivity of filamentous fungi to chitosan. Molecular Microbiology 75(4):10211032. https://doi.org/10.1111/j.1365-2958.2009.07039.x

Peter S, Lyczko N, Gopakumar D, Maria HJ, Nzihou A, Thomas S (2020). Chitin and chitosan-based composites for energy and environmental applications: a review. Waste and Biomass Valorization 1-28. https://doi.org/10.1007/s12649-020-01244-6

Philibert T, Lee B, Fabien N (2017). Current status and new perspectives on chitin and chitosan as functional biopolymers. Applied Biochemistry and Biotechnology 181(4):1314-1337.

Rahman M, Mukta JA, Sabir AA, Gupta DR, Mohi-Ud-Din M, Hasanuzzaman M, ... Islam MT (2018). Chitosan biopolymer promotes yield and stimulates accumulation of antioxidants in strawberry fruit. PloS One 13(9):e0203769. https://doi.org/10.1371/journal.pone.0203769

Rajan A, Kurup JG, Abraham TE (2005). Biosoftening of arecanut fiber for value added products. Biochemical Engineering Journal 25(3):237-242. https://doi.org/10.1016/j.bej.2005.05.011

Rasti H, Parivar K, Baharara J, Iranshahi M, Namvar F (2017). Chitin from the mollusc Chiton: extraction, characterization and chitosan preparation. Iranian Journal of Pharmaceutical Research 16(1):366-379.

Rocha M, Coimbra M, Nunes C (2017). Applications of chitosan and their derivatives in beverages: a critical review. Current Opinion in Food Science 15: 61-69. https://doi.org/10.1016/j.cofs.2017.06.008

Santos V, Marques N, Maia P, Lima M, Franco L, Campos-Takaki G (2020). Seafood waste as attractive source of chitin and chitosan production and their applications. International Journal of Molecular Sciences 21(12):4290. https://doi.org/10.3390/ijms21124290 
Sathiyabama M, Parthasarathy R (2016). Biological preparation of chitosan nanoparticles and its in vitro antifungal efficacy against some phytopathogenic fungi. Carbohydrate Polymers 151:321-325. https://doi.org/10.1016/j.carbpol.2016.05.033

Sayari N, Sila A, Abdelmalek B, Abdallah R, Ellouz-Chaabouni S, Bougatef A, ... Balti R (2016). Chitin and chitosan from the Norway lobster by-products: Antimicrobial and anti-proliferative activities. International Journal of Biological Macromolecules 87:163-171. https://doi.org/10.1016/j.ijbiomac.2016.02.057

Schelegueda LI, Zalazar AL, Gliemmo MF, Campos CA (2016). Inhibitory effect and cell damage on bacterial flora of fish caused by chitosan, nisin and sodium lactate. International Journal of Biological Macromolecules 83:396-402. https://doi.org/10.1016/j.ijbiomac.2015.11.033

Shamshina JL, Kelly A, Oldham T, Rogers RD (2020). Agricultural uses of chitin polymers. Environmental Chemistry Letters 18:53-60. https://doi.org/10.1007/s10311-019-00934-5

Silva WB, Silva GMC, Santana DB, Salvador AR, Medeiros DB, Belghith I, ... Misobutsi GP (2018). Chitosan delays ripening and ROS production in guava (Psidium guajava L.) fruit. Food Chemistry 242:232-238. https://doi.org/10.1016/j.foodchem.2017.09.052

Soliva RC, Elez P, Sebastián M, Martín O (2000). Evaluation of browning effect on avocado purée preserved by combined methods. Innovative Food Science and Emerging Technologies 1(4):261-268. https://doi.org/10.1016/S14668564(00)00033-3

Song Z, Li G, Guan F, Liu W (2018). Application of chitin/chitosan and their derivatives in the papermaking industry. Polymers 10(4):389. https://doi.org/10.3390/polym 10040389

Spadaro D, Droby S (2016). Development of biocontrol products for postharvest diseases of fruit: the importance of elucidating the mechanisms of action of yeast antagonists. Trends in Food Science and Technology 47:39-49. https://doi.org/10.1016/j.tifs.2015.11.003

Srinivasan H, Kanayairam V, Ravichandran R (2018). Chitin and chitosan preparation from shrimp shells Penaeus monodon and its human ovarian cancer cell line, PA-1. International Journal of Biological Macromolecules 107:662-667. https://doi.org/10.1016/j.ijbiomac.2017.09.035

Sun C, Fu D, Jin L, Chen M, Zheng X, Yu T (2018). Chitin isolated from yeast cell wall induces the resistance of tomato fruit to Botrytis cinerea. Carbohydrate Polymers 199:341-352. https://doi.org/10.1016/j.carbpol.2018.07.045

Taşkın P, Canısağ H, Şen M (2014). The effect of degree of deacetylation on the radiation induced degradation of chitosan. Radiation Physics and Chemistry 94:236-239. https://doi.org/10.1016/j.radphyschem.2013.04.007

Tolaimate A, Desbrieres J, Rhazi M, Alagui A (2003). Contribution to the preparation of chitins and chitosans with $\begin{array}{llll}\text { controlled physico-chemical } & \text { 44(26):7939-7952. }\end{array}$ https://doi.org/10.1016/j.polymer.2003.10.025

Uragami T, Saito T, Miyata T (2015). Pervaporative dehydration characteristics of an ethanol/water azeotrope through various chitosan membranes. Carbohydrate Polymers 120:1-6. https://doi.org/10.1016/j.carbpol.2014.11.032

Vanti GL, Masaphy S, Kurjogi M, Chakrasali S, Nargund VB (2020). Synthesis and application of chitosan-copper nanoparticles on damping off causing plant pathogenic fungi. International Journal of Biological Macromolecules 156:1387-1395. https://doi.org/10.1016/j.ijbiomac.2019.11.179

Varamin JK, Fanoodi F, Sinaki JM, Rezvan S, Damavandi A (2020). Foliar application of chitosan and nano-magnesium fertilizers influence on seed yield, oil content, photosynthetic pigments, antioxidant enzyme activities of sesame (Sesamum indicum L.) under water-limited conditions. Notulae Botanicae Horti Agrobotanici Cluj-Napoca 48(4):2228-2243. https://doi.org/10.15835/nbha48411852

Verlee A, Mincke S, Stevens CV (2017). Recent developments in antibacterial and antifungal chitosan and its derivatives. Carbohydrate Polymers 164:268-283. https://doi.org/10.1016/j.carbpol.2017.02.001

Vinsova J, Vavrikova E (2008). Recent advances in drugs and prodrugs design of chitosan. Current Pharmaceutical Design 14(13):1311-1326.

Vlot AC, Sales JH, Lenk M, Bauer K, Brambilla A, Sommer A, ... Nayem S (2020). Systemic propagation of immunity in plants. New Phytologist 229:1234-1250. https://doi.org/10.1111/nph.16953

Waldmann T, Jeblick W, Kauss H (1988). Induced net $\mathrm{Ca}^{2+}$ uptake and callose biosynthesis in suspension-cultured plant cells. Planta 173(1):88-95. https://doi.org/10.1007/BF00394492

Wang K, Li T, Chen S, Li Y, Rashid A (2020a). The biochemical and molecular mechanisms of softening inhibition by chitosan coating in strawberry fruit (Fragaria $x$ ananassa) during cold storage. Scientia Horticulturae 271:109483. https://doi.org/10.1016/j.scienta.2020.109483 
Wang L, Wu H, Qin G, Meng X (2014). Chitosan disrupts Penicillium expansum and controls postharvest blue mold of jujube fruit. Food Control 41:56-62. https://doi.org/10.1016/j.foodcont.2013.12.028

Wang Q, Zuo JH, Wang Q, Yang NA, Gao LP (2015). Inhibitory effect of chitosan on growth of the fungal phytopathogen, Sclerotinia sclerotiorum, and sclerotinia rot of carrot. Journal of Integrative Agriculture 14(4):691-697. https://doi.org/10.1016/S2095-3119(14)60800-5

Wang W, Xue C, Mao X (2020b). Chitosan: Structural modification, biological activity and application. International Journal of Biological Macromolecules 164:4532-4546. https://doi.org/10.1016/j.ijbiomac.2020.09.042

Wang X, Du Y, Liu H (2004). Preparation, characterization and antimicrobial activity of chitosan-Zn complex. Carbohydrate Polymers 56(1):21-26. https://doi.org/10.1016/j.carbpol.2003.11.007

Wang Y, Li B, Zhang X, Peng N, Mei Y, Liang Y (2017). Low molecular weight chitosan is an effective antifungal agent against Botryosphaeria sp. and preservative agent for pear (Pyrus) fruits. International Journal of Biological Macromolecules 95:1135-1143. https://doi.org/10.1016/j.ijbiomac.2016.10.105

Xia W, Liu P, Zhang J, Chen J (2011). Biological activities of chitosan and chitooligosaccharides. Food Hydrocolloids 25(2):170-179. https://doi.org/10.1016/j.foodhyd.2010.03.003

Yang H, Zhang Y, Zhou F, Guo J, Tang J, Han Y, ... Fu C (2021). Preparation, bioactivities and applications in food industry of chitosan-based maillard products: A review. Molecules 26(1):166. https://doi.org/10.3390/molecules26010166

Yang T, Poovaiah B (2002). Hydrogen peroxide homeostasis: activation of plant catalase by calcium/calmodulin. Proceedings of the National Academy of Sciences 99(6):4097-4102. https://doi.org/10.1073/pnas.052564899

Ye W, Sun Y, Tang Y, Zhou W (2021). Biocontrol potential of a broad-spectrum antifungal strain Bacillus amyloliquefaciens B4 for postharvest loquat fruit storage. Postharvest Biology and Technology 174:111439. https://doi.org/10.1016/j.postharvbio.2020.111439

Yin H, Du Y, Dong Z (2016). Chitin oligosaccharide and chitosan oligosaccharide: two similar but different plant elicitors. Frontiers in Plant Science 7:522. https://doi.org/10.3389/fpls.2016.00522

Yin H, Du Y, Zhang J (2009). Low molecular weight and oligomeric chitosans and their bioactivities. Current Topics in Medicinal Chemistry 9(16): 1546-1559. https://doi.org/10.2174/156802609789909795

Yin H, Li Y, Zhang HY, Wang WX, Lu H, Grevsen K, ... Du Y (2013). Chitosan oligosaccharides-triggered innate immunity contributes to oilseed rape resistance against Sclerotinia sclerotiorum. International Journal of Plant Sciences 174(4):722-732. https://doi.org/10.1086/669721

Zuppini A, Baldan B, Millioni R, Favaron F, Navazio L, Mariani P (2004). Chitosan induces $\mathrm{Ca}^{2+}$-mediated programmed cell death in soybean cells. New Phytologist 161(2):557-568.
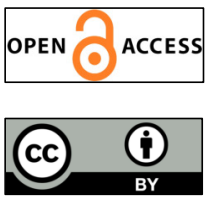

The journal offers free, immediate, and unrestricted access to peer-reviewed research and scholarly work. Users are allowed to read, download, copy, distribute, print, search, or link to the full texts of the articles, or use them for any other lawful purpose, without asking prior permission from the publisher or the author.

License - Articles published in Notulae Botanicae Horti Agrobotanici Cluj-Napoca are Open-Access, distributed under the terms and conditions of the Creative Commons Attribution (CC BY 4.0) License.

(c) Articles by the authors; UASVM, Cluj-Napoca, Romania. The journal allows the author(s) to hold the copyright/to retain publishing rights without restriction. 